\title{
MODIFICATION OF ITU-R RAIN FADE SLOPE PREDICTION MODEL BASED ON SATELLITE DATA MEASURED AT HIGH ELEVATION ANGLE
}

\author{
HaSsan DaO, MD. RAFiqul ISLAM AND KHALID Al-KHATEEB \\ Electrical and Computer Engineering Department, \\ Faculty of Engineering, International Islamic University Malaysia, \\ Jalan Gombak, 53100 Kuala Lumpur, Malaysia. \\ rafiq@iium.edu.my
}

\begin{abstract}
Rain fade slope is one of fade dynamics behaviour used by system engineers to design fade mitigation techniques (FMT) for space-earth microwave links. Recent measurements found that fade slope prediction model proposed by ITU-R is unable to predict fade slope distribution accurately in tropical regions. Rain fade measurement was conducted in Kuala Lumpur $(3.3 \square \mathrm{N}, 101.7 \square \mathrm{E})$ where located in heavy rain zone by receiving signal at $10.982 \mathrm{GHz}$ (Ku-band) from MEASAT3 (91.5 E) on 77.4 $\square$ elevation angle. The measurement has been carried out for one year period. Fade slope S parameter on ITU-R prediction model has been investigated. New parameter is proposed for the fade slope prediction modeling based on measured data at high elevation angle, Ku-band.
\end{abstract}

ABSTRAK: Cerun hujan pudar adalah salah satu dinamik tingkah laku pudar yang digunakan oleh jurutera sistem untuk mereka bentuk teknik-teknik pengurangan pudar (FMT) bagi link gelombang mikro ruang bumi. Ukuran baru-baru ini mendapati bahawa cerun pudar ramalan model yang dicadangkan oleh ITU-R tidak mampu untuk meramalkan pengagihan cerun pudar tepat di kawasan tropika. Pengukuran hujan pudar telah dijalankan di Kuala Lumpur (3.3 $\square$ N, 101.7 $\square$ E) yang terletak di kawasan hujan lebat dengan menerima isyarat pada 10,982 GHz (Ku-band) dari MEASAT3 (91.5 $\square$ E) pada sudut ketinggian 77.4 $\square$. Pengukuran telah dijalankan untuk tempoh satu tahun. Parameter cerun pudar S pada model ramalan ITU-R telah disiasat. Parameter baru adalah dicadangkan untuk pemodelan cerun pudar ramalan berdasarkan data yang diukur pada sudut paras ketinggian, Ku-band.

KEYWORDS: fade slope; ITU-R; fade mitigation techniques; sampling time interval

\section{INTRODUCTION}

In satellite communication on frequencies above $10 \mathrm{GHz}$, rain attenuation is great propagation phenomenon that influence large variations in received signal levels. Rain attenuaton is inordinately degraded received signal. That is why many mitigating approachs have been developed to reduce fading outage of communication links.

Rain attenuation behaviours are extensively studied and measured but dynamic aspect of rain attenuation still has sparse study. Knowledge on rain fade dynamics is noticeable important in the design of new satellite communication systems. Adaptive power control (APC) and Uplink power control (ULPC) are ones of rain countermeasure techniques relies on rain fade dynamics parameters by increasing transmitted power to compensate rain fading on propagation path. fade slope is one behaviour of fade dynamics 
characteristics that assesses tracking speed contributing factor to fade mitigation techniques (FMT) [1, 2]

Various researchers have studied and proposed parameters and prediction models for rain fade slope. Most studies have based on temperate region measurements [1, 3-7]. ITUR P.1623 [8] has recommended a prediction model for fade slope based on Van De Kamp model $[3,4]$ measured at Netherlands receiving signal from Olympus satellite $(\mathrm{El}=$ $26.78^{\circ}$ ) on 12.5 - $30 \mathrm{GHz}$. The model was examined using data from other sites in the UK, France, Belgium, Italy, and the US [1]. However, some measurements [9] in tropical zones have indicated the model is required to improve in order to correspond to different climate zones.

This paper analyses rain fade slopes characteristic on different sampling times and comparing between available model and measurement in Kuala Lumpur, Malaysia. Fade slope $\mathrm{S}$ parameters has also been focused and proposed on high elevation angle as a function of different fade levels.

\section{EXPERIMENTAL SETUP}

Experimental system has been monitored signal from MEASAT 3 (geostationar

E) at $10.982 \mathrm{GHz}$ frequency (Ku-Band), vertical polarization with QPSK modulation provided 15 channels for Malaysian direct broadcast satellite (DBS) pay television service (Astro). The received signal level has been collected for 12 months perio

. Fig. 1 and

Table 1 have summarized experimental setup and system parameters, respectively at Satellite Communication lab, IIUM.

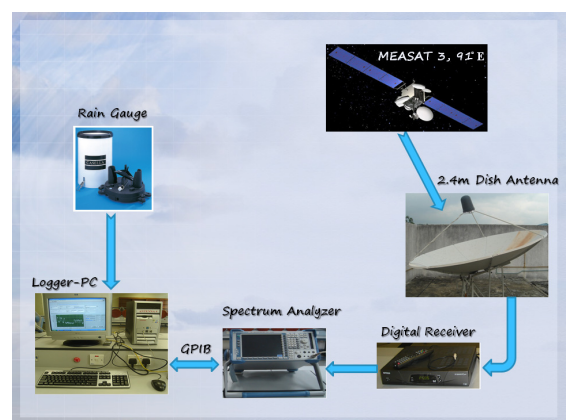

Fig. 1: Experimental setup for measurement at Ku-band signal over earth-space path at Satellite Communications Lab, IIUM.

Table 1: System parameters of the link.

\begin{tabular}{|l|c|}
\hline Ground Station Location & $3.3^{\circ} \mathrm{N}, 101.7^{\circ} \mathrm{E}$ \\
\hline Beacon Frequency & $10.982 \mathrm{GHz}(\mathrm{IF}=1.232 \mathrm{GHz})$ \\
\hline Satellite Position & $91.5^{\circ} \mathrm{E}$ (MEASAT 3) \\
\hline Polarization & Vertical \\
\hline Azimuth & $253^{\circ}$ \\
\hline Elevation Angle & $77.4^{\circ}$ \\
\hline Antenna Diameter & $2.4 \mathrm{~m}$ \\
\hline NF of LNB & $0.3 \mathrm{~dB}$ \\
\hline
\end{tabular}


Signal from MEASAT3 has been received by $2.4 \mathrm{~m}$ diameter of parabolic dish antenna with Low noise block (LNB), $0.3 \mathrm{~dB}$ noise figure. The signal is down converted to Intermediate Frequency (IF) as L-band with Local Oscillator (LO) $975 \mathrm{MHz}$. The subsequent IF is sent to spectrum analyzer setting post-detection bandwidth (video bandwidth) of $10 \mathrm{~Hz}$ [10] to monitor carrier signal and remove spurious noise. Consequent Output signal from spectrum analyzer is logged and saved in databank by using software developed with sampling time interval of 1s. In addition, rainfall rate is also measured synchronously by $0.2 \mathrm{~mm}$-Tipping bucket rain gauge every $10 \mathrm{~s}$ time interval.

\section{FADE SLOPE MODEL PROPOSED BY ITU-R}

ITU-R has proposed statistical distribution model of fade slope developed by Van De Kamp [1, 11] that depends on cutoff frequency, attenuation and sampling time. The proposed prediction model of probability density function (PDF) is shown Eq. 1,

$$
p(\xi \mid A)=\frac{2}{\pi \sigma_{\zeta}\left(1+\left(\xi / \sigma_{\xi}\right)^{2}\right)^{2}}(d B / s)^{-1}
$$

Where $\sigma_{\xi}$ is the standard deviation of the conditional fade slope at a given attenuation level given by,

$$
\begin{array}{rl}
\sigma_{\zeta}=s & F\left(f_{B}, \Delta t\right) A \mathrm{~dB} / \mathrm{s} \\
\text { Where }_{F\left(f_{B}, \Delta t\right)}=\sqrt{\frac{2 \pi^{2}}{\left(1 / f_{B}^{b}+(2 \Delta t)^{b}\right)^{1 / b}}}
\end{array}
$$

With $b=2.3, f_{B}$ is the $3 \mathrm{~dB}$ cutoff frequency of the low pass filter $(\mathrm{Hz})$, and $\mathrm{S}$ parameter is from experiment as derived above.

\section{DATA PRE-PROCESSING}

\subsection{Clear sky reference level}

Finding out zero $\mathrm{dB}$ reference level from clear sky on measurement of satellite signal attenuation is a fundamental trouble requirement. Defining clear sky reference level by hourly averaging after and before raining days [12]. Raining events were determined on 10s interval time for tipping bucket type of rain gauge. The number of data points (second) during raining events used to generate fade slope for each attenuation values are shown in Fig.3. It is obvious that the number of occurrences decreases with attenuation levels.

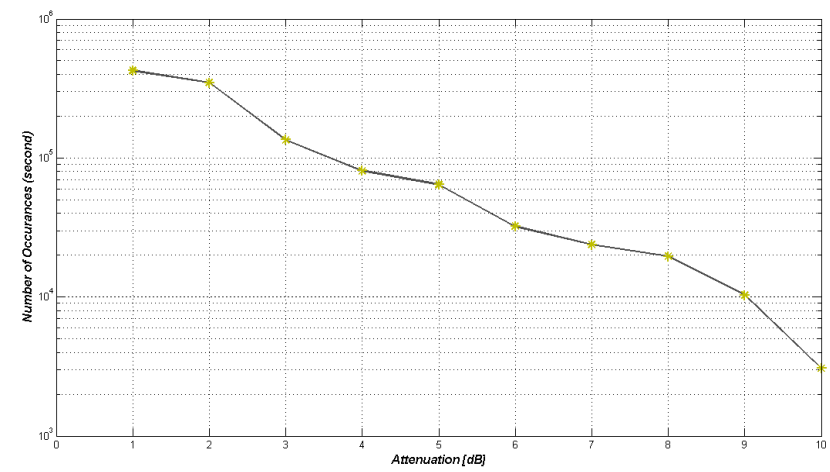

Fig. 3: Number of time series (second) extracted from data measured from July 1, 2010 to June 30, 2011. 


\subsection{Rain Attenuation and Scintillation Extraction}

Attenuation time series during raining events are contaminated by fast fluctuations due to tropospheric scintillation. Therefore, tropospheric scintillation is essentialy decimated prior to proceed next processes [13]. Power spectral density (PSD) is efficient technique in order to separate propagation due to scintillation and rain attenuation by specifying appropriate cutoff frequency $\left(f_{c}\right)[14,15]$. High pass filter (HPF) order $6^{\text {th }}$ of Digital Butterworth filter with cutoff frequency of $0.025 \mathrm{~Hz}$ [16] obtained by the PSD function and has been implemented to remove fast fluctuation due to scintillation.

\section{DATA ANALYSIS AND RESULTS}

Fade slopes are calculated for each attenuation level thresholds after tropospheric scintillation has been decimated. Each attenuation level $(\mathrm{dB}), A$ is calculated when $A-0.5<A(t) \leq A+0.5 d B$, then fade slope is calculated by Eq. (4)

$$
\delta(t)=\frac{A(i+\Delta t)-A(i-\Delta t)}{2 \Delta t} \quad(d B / s)
$$

Where $\Delta \mathrm{t}$ is sampling time, $1 \mathrm{~s}$ and $i$ is sample number.

\subsection{Comparison Between Measured Data and Prediction Model}

Once fast fluctuation due to tropospheric scintillation has been decimated from the signal, fade slope has been calculated from Eq. 4. The prediction model has been calculated by Eq. 1 using $f_{B} 25 \mathrm{mHz}$ obtained from the experiment, $\Delta t 1 \mathrm{~s}$ and $S=0.01$ (ITU-R proposed). Comparison of measurement and model has been depicted in Fig. 4.

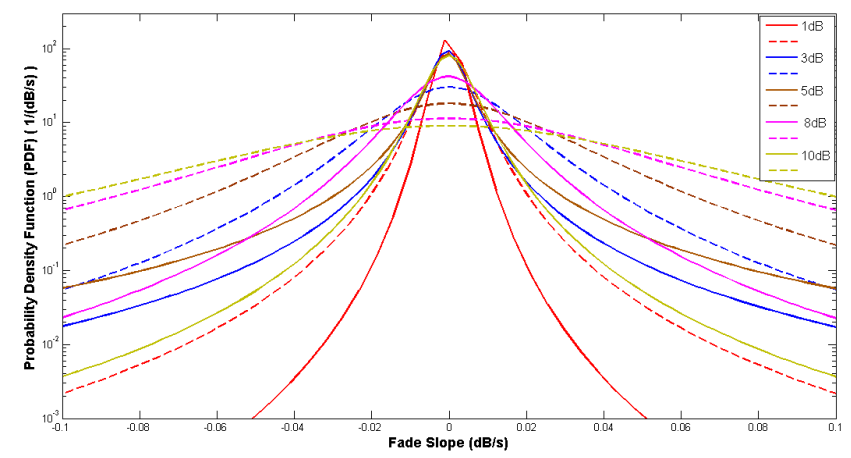

Fig. 4: PDF comparison between fitting of measured data (solid line) and ITU-R (dash line) model for 1s sampling time.

\subsection{Investigation of Standard Deviation}

Rain fade slope characteristic has been investigated to evaluate the parameters for ITU-R [8] based on the measured data. Principal parameters analysis was focused on standard deviation $\left(\sigma_{\zeta}\right)$ with different attenuation thresholds. The measured standard deviation and the model have been presented as a function of attenuation thresholds in Fig. 5 (a).

Measured $\sigma_{\zeta}$ indicated that keeps increasing with attenuations from $0.0038 \mathrm{~dB} / \mathrm{s}$ and reaching maximum $0.018 \mathrm{~dB} / \mathrm{s}$ at $6 \mathrm{~dB}$ attenuation and subsequently reducing until 0.0079 
$\mathrm{dB} / \mathrm{s}$ at $10 \mathrm{~dB}$. Standard deviation, $\sigma_{\zeta}$ was estimated by ITU-R prediction model indicated that $\sigma_{\zeta}$ increased linearly with attenuation levels.

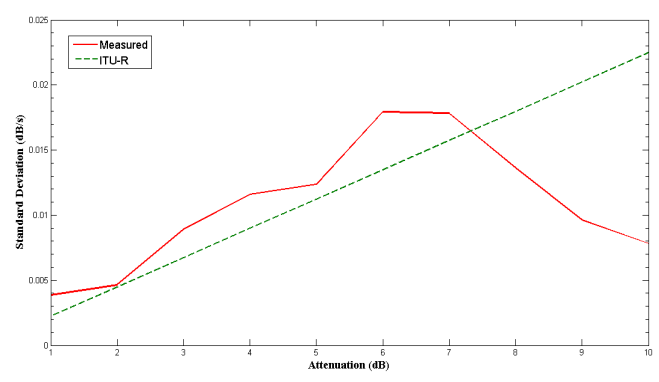

(a)

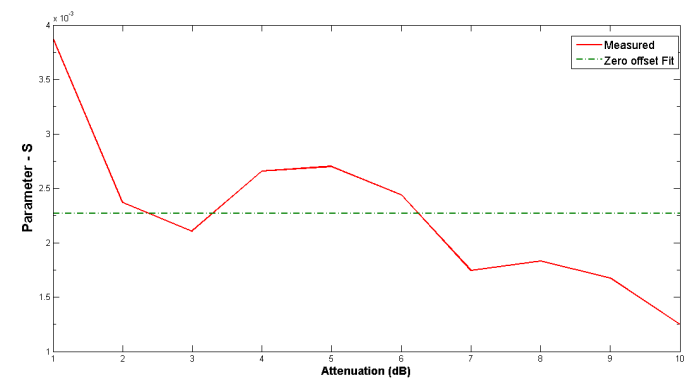

(b)

Fig. 5: (a)Comparison of standard deviations between measured data (solid line) and predicted by ITU-R prediction models (dash line), (b) The measured value of $S$ as a function of attenuations between measurement (solid line) and Zero Offset fit (ZOF) (dash line).

\subsection{Proposed Standard Deviation}

ITU-R prediction model has been proposed $\sigma_{\zeta}$ which depends on $f_{B}, \Delta t$ and parameter $S$. Parameter $S$ is a constant which depends on climate and elevation angle which affect to $\sigma_{\zeta}$ of ITU-R model. ITU-R has proposed the constant averagely at 0.01 in Europe and USA at elevation angle between $10 \square-60 \square$. But there is no model proposed in tropical region and on high elevation angle. Therefore, $S$ is needed to derive in order to propose for the model on this region and high elevation angle. Parameter $S$ is obtained by Eq. (5) using $\sigma_{\zeta}$ from the experiment and has been presented by Fig. 5(b).

$$
S=\frac{\sigma_{\delta}}{F\left(f_{B}, \Delta t\right) A}
$$

Thus, determination of empirical $S$ is implemented by Zero offset Fit (ZOF) [2, 3, 4] yielded 0.0023 to propose in the model for this characteristics.

\subsection{Comparison with the Model}

Statistical distribution comparisons between measurement and model with different parameter $S$ have been depicted in Fig. 6(a) and 6(b) as a function of attenuations. Figure 6 illustrates fade slope distribution comparison between measured data and the propoaed model. The models are drawn S parameters as applying Zero offset fit (ZOF) method. PDF's predicted by ZOF is closer fit with the measurement for attenuation between $1 \mathrm{~dB}$ $6 \mathrm{~dB}$. For attenuation higher than $6 \mathrm{~dB}$, the model shows wider with attenuations while the measurement showd narrower with attenuations corresponding to standard deviations.

Table 2: Descriptive PDF Statistics comparison between measurement and models.

\begin{tabular}{|c|l|r|r|r|r|r|}
\hline \multicolumn{2}{|c|}{ Attenuation $(\mathrm{dB})$} & \multicolumn{1}{c|}{1} & \multicolumn{1}{c|}{3} & \multicolumn{1}{c|}{6} & \multicolumn{1}{c|}{8} & \multicolumn{1}{c|}{10} \\
\hline \multirow{2}{*}{ Mean } & Measured & 3.311 & 3.308 & 3.306 & 3.31 & 3.311 \\
\cline { 2 - 7 } & ZOF & 3.357 & 3.311 & 3.31 & 3.309 & 3.307 \\
\hline \multirow{2}{*}{ SD } & Measured & 17.42 & 13.181 & 7.785 & 8.747 & 12.548 \\
\cline { 2 - 7 } & ZOF & 25.123 & 13.626 & 9.345 & 7.921 & 6.929 \\
\hline \multirow{2}{*}{ Skewness } & Measured & 6.403 & 5.24 & 2.859 & 3.19 & 4.702 \\
\cline { 2 - 7 } & ZOF & 9.864 & 5.105 & 3.419 & 2.85 & 2.449 \\
\hline \multirow{2}{*}{ Kurtosis } & Measured & 43.185 & 28.818 & 7.413 & 9.573 & 22.645 \\
\cline { 2 - 7 } & ZOF & 105.662 & 26.963 & 11.22 & 7.316 & 4.996 \\
\hline
\end{tabular}




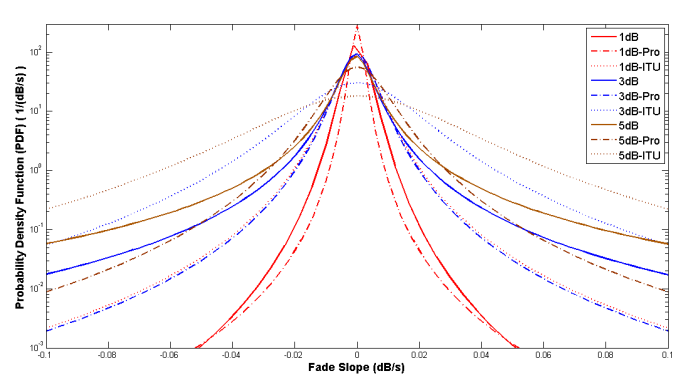

(a)

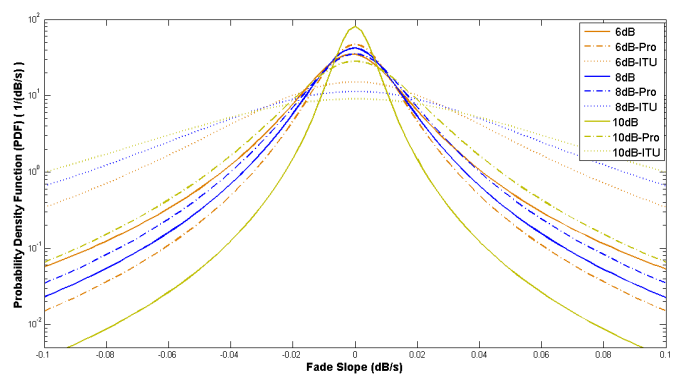

(b)

Fig. 6: PDF comparison among Measurement and model with different values of sparameters of (a) $1 \mathrm{~dB}$ to $5 \mathrm{~dB}$ attenuations and (b) $6 \mathrm{~dB}$ to $10 \mathrm{~dB}$ attenuations levels.

\section{CONCLUSION}

Rain fade was measured in Kuala Lumpur $\left(3.3^{0} \mathrm{~N}, 101.7^{0} \mathrm{E}\right)$ at $10.982 \mathrm{GHz}(\mathrm{Ku}-$ band) from MEASAT3 $\left(91.5^{\circ} \mathrm{E}\right)$ on $77.4^{0}$ elevation angle. The measurement has been carried out for one year period. Fade slope S parameter on ITU-R prediction model has been investigated based on data processed with $1 \mathrm{sec}$ integration time. The probability distribution functions proposed by ITU-R with parameter $S=0.01$ are much wider than the measurement for all attenuation levels. The value of $S$ parameter is evaluated using implemention of Zero offset Fit (ZOF) with measured data. The new value of $S=0.0023$ is proposed in the fade slope prediction model for high elevation angle, Ku-band in tropical regions.

\section{ACKNOWLEDGEMENT}

The authors are very grateful to the Research Management Centre (RMC), International Islamic University Malaysia (IIUM) for research grant supporting this project.

\section{REFERENCES}

[1] L. Castanet and M.V. de Kamp, "Modelling the Dynamic properties of the propagation channel", 5th Management Committee Meeting of the COST 280 Action, May 2003

[2] Chambers, A.P., Callaghan S.A. and Otung, I.E., "Analysis of rain fade slope for Ka and VBand satellite links in southern England", IEEE Transac. On Antenna and Propagation, Vol.54, No.5, May 2006.

[3] M.J.L. Van de Kamp, "Statistical Analysis of Rain Fade Slope", IEEE Transac. On Antenna and Propagation, Vol.51, No.8, August 2003

[4] M.M.J.L. Van de Kamp, "Climatic Radiowave Propagation Models for the design of Satellite Communication Systems", Ph.D. Thesis, Eindhoven University of Technology, Eindhoven, the Netherlands, ISBN 90-386-1700-3, Section 4, 1999.

[5] E. Matricciani, "Rate of change of signal attenuation from Sirio at $11.6 \mathrm{GHz}$ ", Electron. lett., Vol.17, No.3,1981

[6] P.D. Baxter, G.J.G. Upton and D. Eden, "Revise method for calculation of rain-fade-slope", Electron. Lett. Vol. 37, No. 10, 2001

[7] Stutzman W.L., Pratt. T., Safaai-Jazi A., Laster J., Nelson B. and Ajaz H. "Results from the Virginia tech propagation experiment using the Olympus satellite 12, 20 and $30 \mathrm{GHz}$ beacons", IEEE Transac. On Antenna and Propagation, Vol.43, No.1, January 1995.

[8] ITU-R P.1623, "Prediction method of fade dynamics on Earth-space paths", ITU, Geneva, Switzerland, 2003. 
[9] F.F. Franklin, K. Fujisaki, and M. Tateiba, "Fade Dynamics on Earth-Space Paths at KuBand in Fukuoka, Japan Fade-Slope Evaluation, Comparison, and Model", IEEE Antenna and Wireless Propagation Letters, Vol. 5, 2006.

[10] Adhikari A. and Maitara A., "Studies on the inter-relation of Ku-band scintillations and rain attenuation over an Earth-space path on the basis of their static and dynamic spectral analysis", Journal of Atmospheric and Solar-Terrestrial Physics (JASTP), Volume 73, Issue 4, November 2010.

[11] H. Dao, MD. R. Islam, K. Al-Khateeb, "Fade Dynamics review of microwave signals on Earth-Space paths at Ku-Band", International Conference on Computer and Communication Engineering Proceeding, May 2008.

[12] Y. Maekawa, T. Fujiwara, Y. Shibagaki, T. Sato, M. Yamamoto, H. Hashiguchi, and S. Fukao "Effects of Tropical Rainfall to the Ku-Band Satellite Communications Links at the Equatorial Atmosphere Radar Observatory", Journal of the Meteorological Society of Japan, Volume 84A, 2006.

[13] MR Islam, H. Dao and AH Zayuod, "Rain Fade Slope Analysis for Terrestrial Microwave Link in Malaysia", $9^{\text {th }}$ Malaysia International Conference on Communications (MICC) Proceeding, December 2009.

[14] Y. Karasawa , T. Matsudo, "Characteristics of Fading on Low-Elevation Angle Earth-Space Paths with Concurrent Rain Attenuation and Scintillation", Vol.39, No.5, May 1991.

[15] I.E. Otung, M.O. Al-Nuaimi, and B.G. Evans, "Extracting Scintillations from satellite beacon propagation data", IEEE Transac. On Antenna \& Propagation, Vol.46, No.10, October 1998.

[16] H. Dao, MR. Islam, K. Al-Khateeb, "Preliminary Analysis of Ku-Band Rain Fade Data for Earth-to-Satellite Path Measured in Malaysia", $10^{\text {th }}$ Malaysia International Conference on Communications (MICC) Proceeding, October 2011 